や筆いをい

者点問 5 社

あがで題と会

る予あとと意

的定乃主は識

はさ 5 る、としむ三二一は

特れ。際そはがす豊営政じ

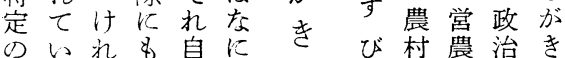

社るど、体か

会で、当然解さ

題 こ然決施

に私の前交に

つは問提大は

的社題とをと

て会にしなれ

的意つて閥を

だ識い明題ど

くをてらでの

8、はかあお

のそ、にる5

ののこさがに

見成小れをそ䛃

や員特くれ把

社 意意

会識識

の KK

動おお

向けけ

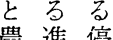

農 進 停

意性 性

識

民

主

課

考が集ては握

え社では農す

方会はな民る

一他ら意か

さ般の六識と

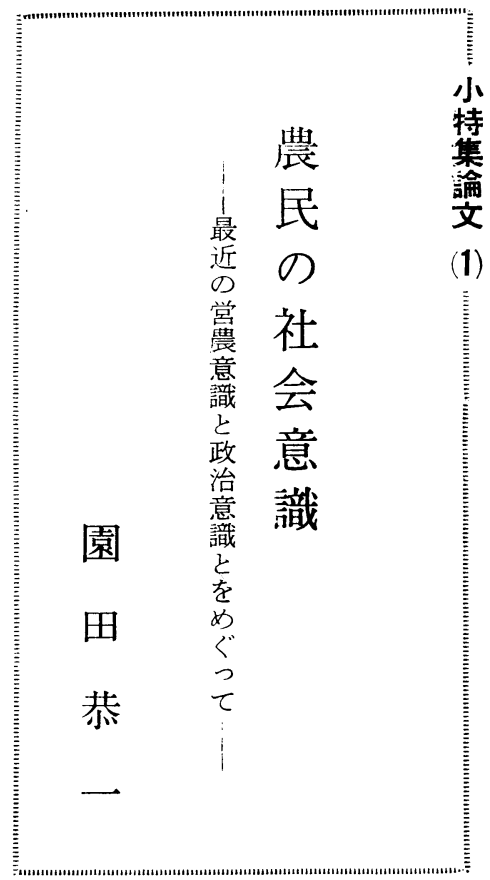

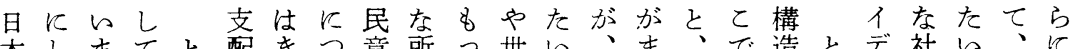

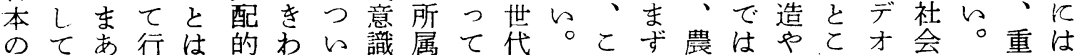

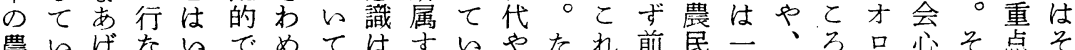

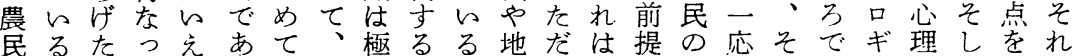
によたる革あめ集と域し後と社前の、1とて農に 共そ5調とし新るて団的疗、のし会提社ての 通とに查の $\widehat{1}$ 的い複や 5 ぞ最行て的と会のいわの意来 すで諸結よしなは雑階と、近論と存し的よずれ与識す ると条果 5 と態そな層とさののり在て存 5 れる 5 のる

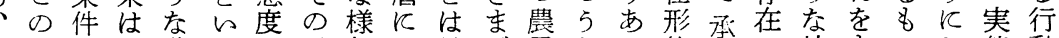
い小に、階 5 を営相よ見ざ民ちつ態認に社8のし態動 わ論よ今層上示農をる落まはに加やさ会含とて把の

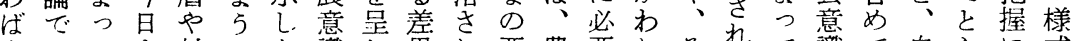
意はてま対にた識し異れ要農要れそれて識て自らに式

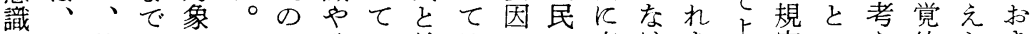

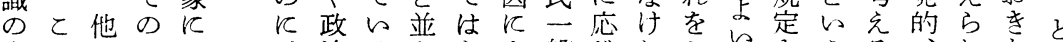

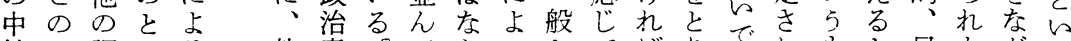
核よ調とる他意。でらうとて壮りでれもを目たがち と 5 查乃差の識た、なてい取なま奇るのい的社ら占 でな事極異場飞と対い: 5 b ら

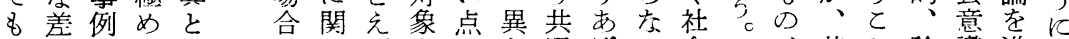
呼異とてい它しばや装な通げい会と、基と論識進広 ばをの少5 はて、分市つ面ると合とと本に理にめ㕕

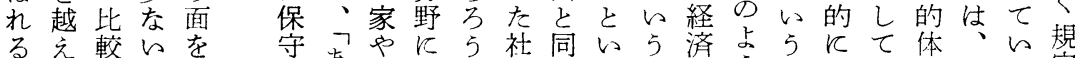

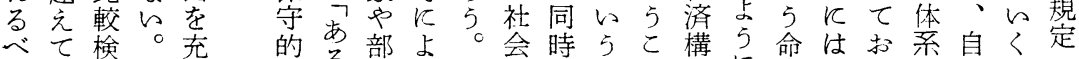

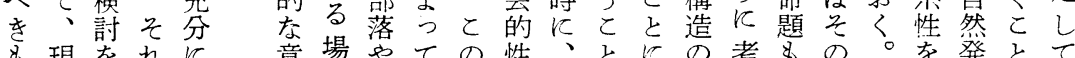

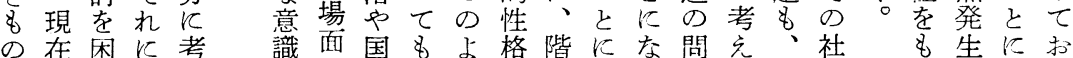

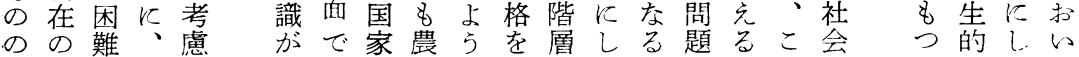




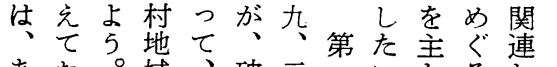

あお。域、破三立的主先民

まら大で極壞○の○し態た主

りず多はめさ居度政主

直、数こて扎を主伀治義

接安のの広た契主民的危程

の保農よ的民機義主わ機に

話強民 5 階主とに主ばの関

題行は告属主しう義政中娄

と採、危の義てら

は決あ機ひを、て

なとの意と守都は

ら和事識でれ市、

な 5 件はと と地安

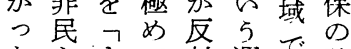

た主まて対運で強

農手や少動に採

民段つつ反戦そ決

のにたた立線れか

安つかと上保ら上的

問てぐ5た大のな

題のら点のさ安わ

に憤的㤎にれ保れ

つり指対た反た

的し摘し の対五

て不出、反闘月

の満考来農伴争一
ட治でる

と㵍没

平筽題主

和るさ

と識た

的加ま性

5 ら農 す

点氐最

点ての初

かに安に

らく保

問と打昨

題とよ年

そにびの

寸寸民安

るる。主保

と義争

いみ第第む手造最分

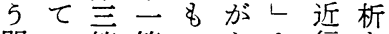

問い節節のかと行を

題くでとのりらな主

\&とは三摘と 50 題

政含と、節出し二たと

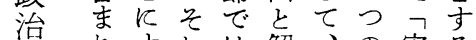

れ寸れは解、の安る

てるら、明と調保乙

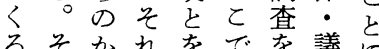

でこらを意は角苓

あでみ政図々い主た

ろはあ治与のる義的

5 当的意る個とと。

然の識と々と農

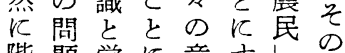

階題嫦億すし手

層を農し竟恶手

や集今意よやがじが

団後亡。応 $\underbrace{}_{7}$ b

にの沉農と

よ動関と仕そ業 し

る向連で方机共て

意とし.、のは同は、

識 \&て 根 あ化

の合取劣底くと筆

違わ上始飞村者 らせげめひで落ら

とて、のそ\&構が

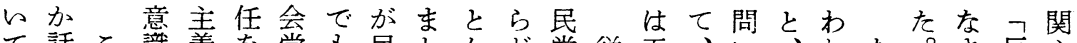

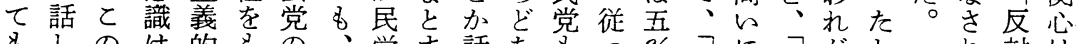

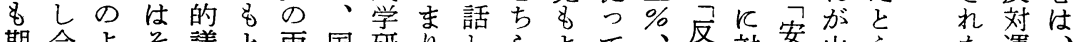

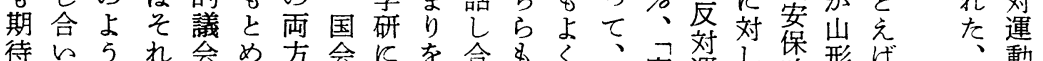

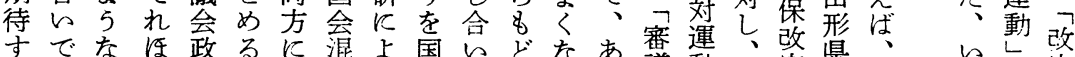

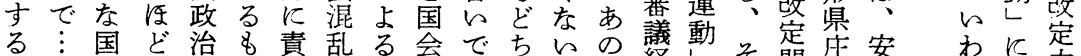
る

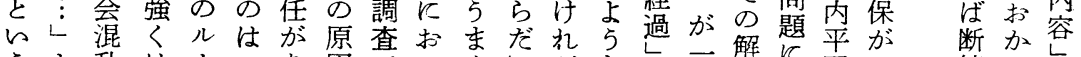
もと乱は

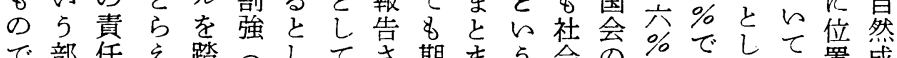
で部任え踏へしてさ期ま5会の底でして置成

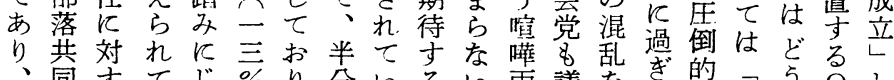

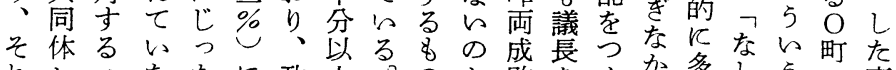
れし喧なたに政上なのか敗をくか多し5 の直 はべ嚾かの寺府乞わがしと暴りっく、点農後

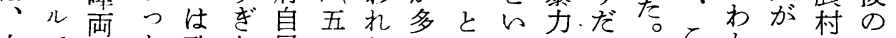

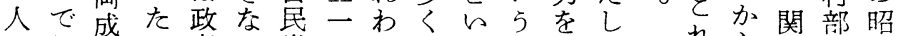
之の敗の府か党\%れみ 5 気使た 基ま的で自つのしのら、持つ責 なと見あ民た多ま $O$ れ部持て任 るま方る党の数で町た落が監に 意りは。でで横がに、やあ禁つ 竟を素市暴自おと村りしい が国ᄀるるに尼け的段、たて

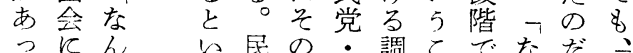
ておと主责社查々のなた れら空落

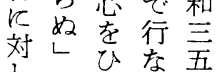
しのらつ年 て五たた苗 次四加調月 定\%七查に 定をと直、 な之審 事れ議 件は経 的文過 関のし 心政よ と治り で的 \& 的景乱 わや䦔 れ意

る味デ べづモ をけ \& 5 र の b 内容除占わ 


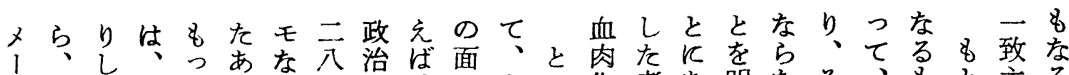

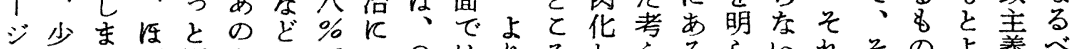

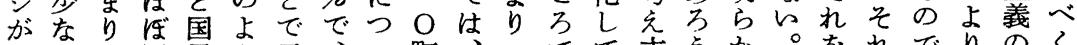
浸くを同民 透々期じのな正ての民般、いを不光同であ民現出 乙\&待く意政べ国は調主的やるもとすれ等はる主わさ

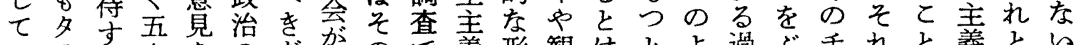

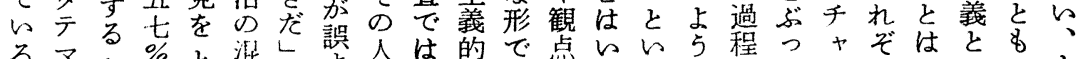

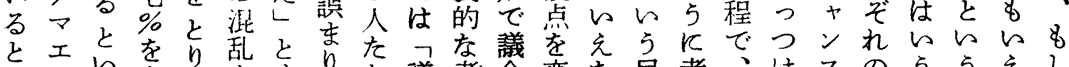

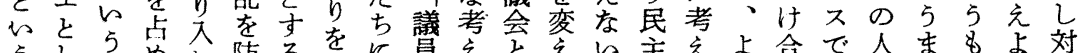

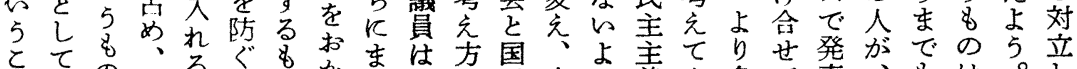

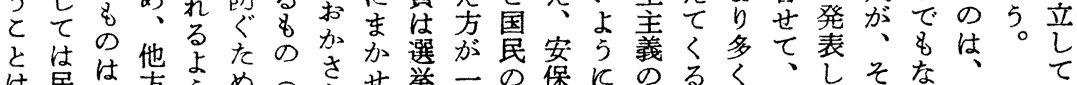

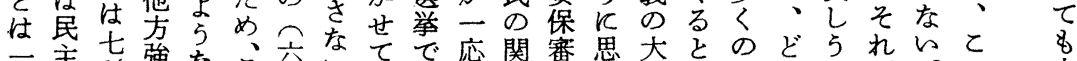

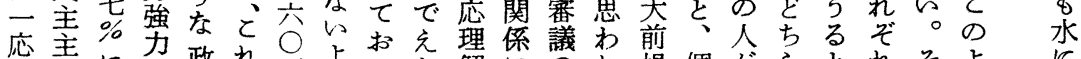

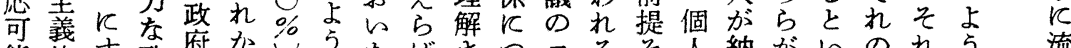
能的す政府かし5た代さつ具ると納が方のれ

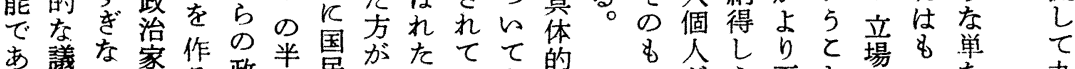

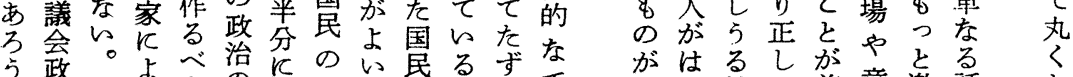

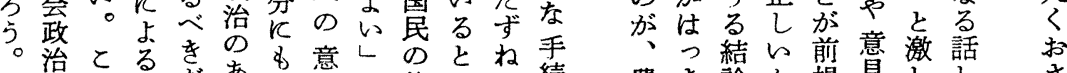
几れ反だあ在壳と代的続農を論か提見ししさ

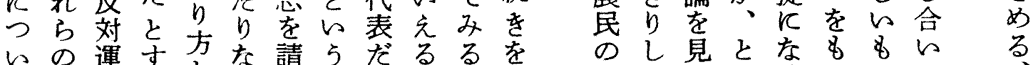

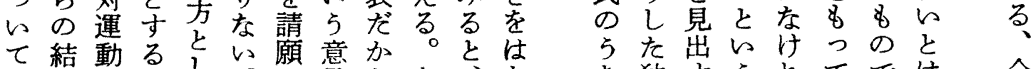

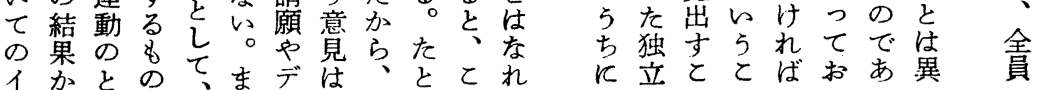

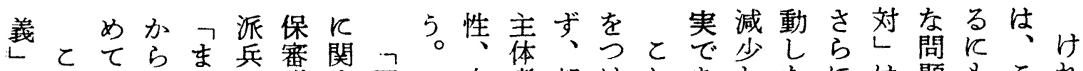
とのい、たの議守平自者部けれあしたとは題\&とれ はとたば戦問のる和登と落るはる怙る問四と拘のど

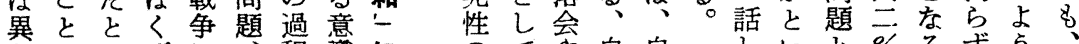
なかいぜに程識にのて自自しいと\%るず

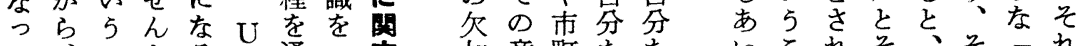

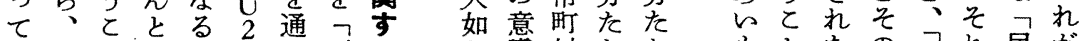

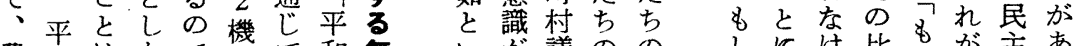
農和はたで撃て和舞的が議ののしにけ比すが主あ

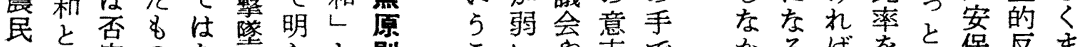
に定のな事らと則と的志でかるばを保反ま お5出でい件かい性とと県を政つと集番の応で 的闌あかやにい会議治た、ら下議審ら観

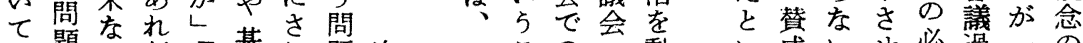

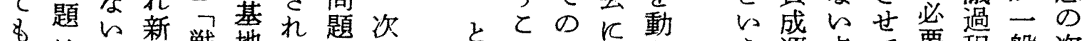

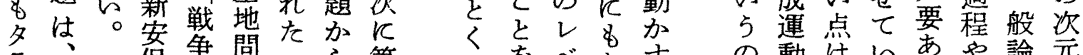

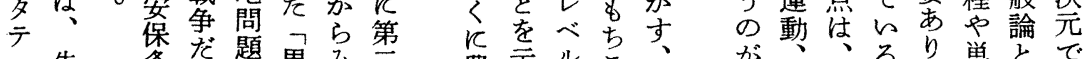

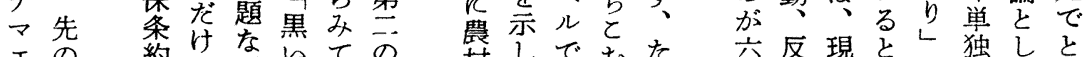

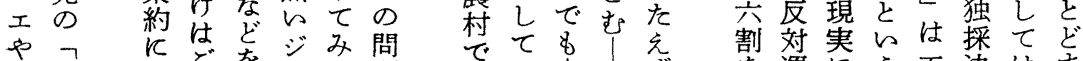

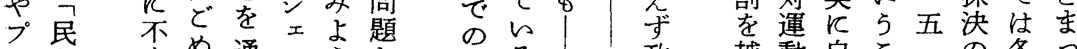

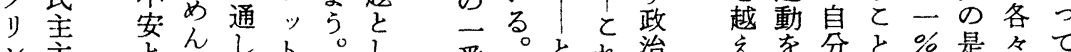

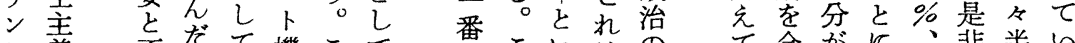

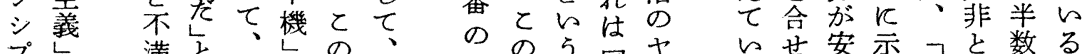
プレ 満と、レの間の5国ヤ ルやをん一問点農閣よ主国り

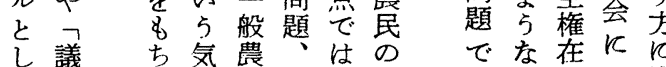
七会は持民海、政市主民限注 壮主じちも外安治 るて保さ単いをと と多問礼独 5 越的 的道採具方 5 5 割で 5 決体てと 事反行。反的以と 


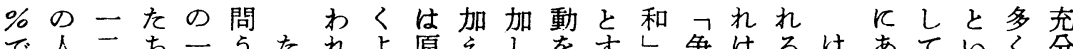

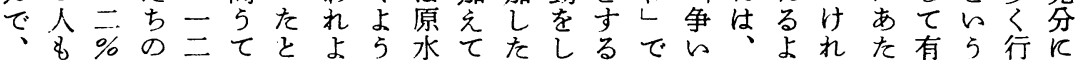

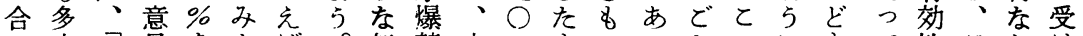

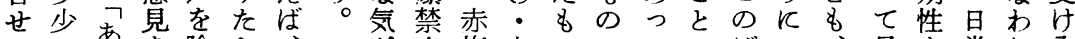
てのあ除と、が歨旗九のでてのばな、見を常れ入

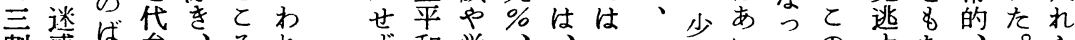

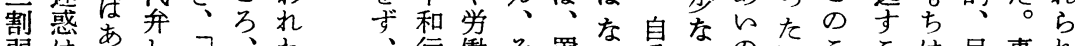

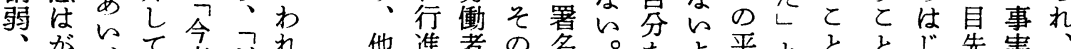
が、て今他進者の名。たょ平とととじ先実

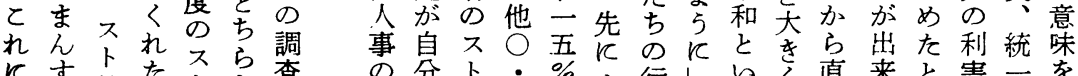

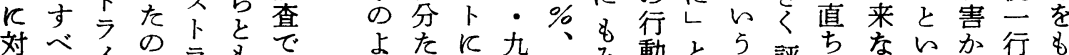

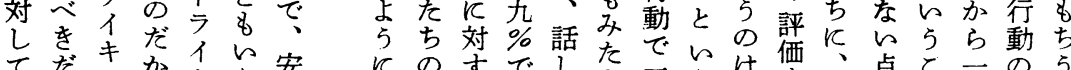

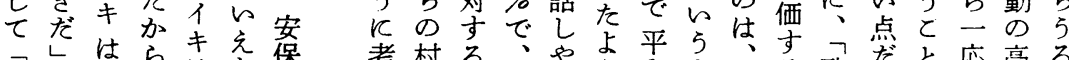

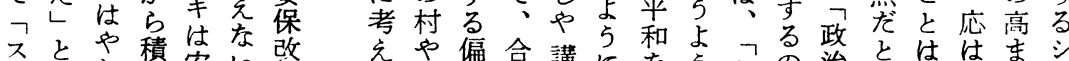

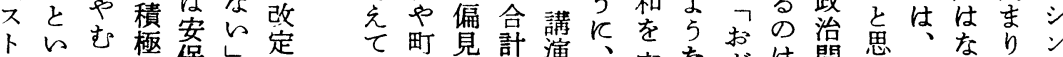
は 5 得的保し足改のを見演、守なだは問

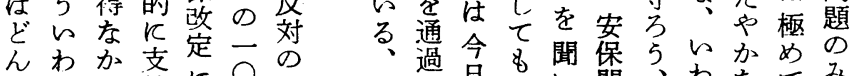
なばつ持に\% ス ば消た村\%、 あ極 のる対 ら的だடすわ対 で支かとるかす 女持らい一らる よが、 5 般な意 く一一ののい見 な七般は人しを

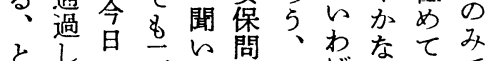
と元で割た題平ば世危で 5 \& \& 弱—で和 ᄀの険 事全強飞\%何を無中で農 実然くす《ん獲原をあ民 かう、ぎら得則のろが らいさなモかし的ぞ5立 窥筧
思、なりン わとれとポ れのたとル るよシ \& 弓ンにあ なボ、る 問ルと 題がのと をそよと य机 55 て自な評 ゆ体平価 くと和 が

あ価てはたは戦て農い自保国み分ととれ和いとい る值い共、農近後極民。加民ら的深いててをとすと 義体な同後民年のめの従らしにれにくわれはめいるは 理系い体のた著いてなっの保るせ関れらなぐ 5 る 人がの的第ちしわ重かて行け障し上係るのらる受の四 情支は意严のくゆ要に、動れ寸 3 生し農事交意けが\% を配、䜅節今営るなど個でばるし活て村実い識と一

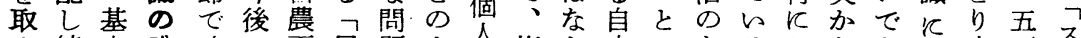

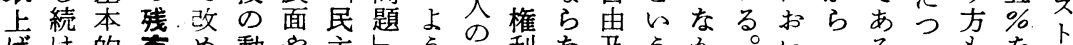

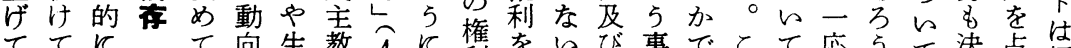

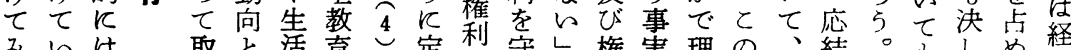

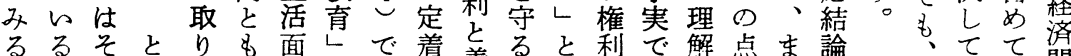
るるそ と り

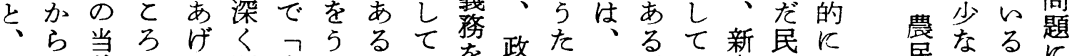

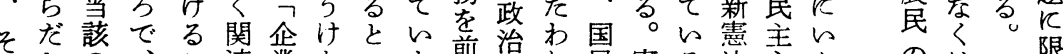
そとの、を連業たいた前治れ居憲る法主えのは限 付集ととし性新えか提動ての法都飞義る主なトる

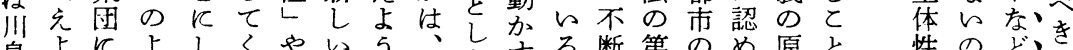

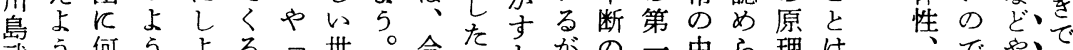
武う。何 5 よ

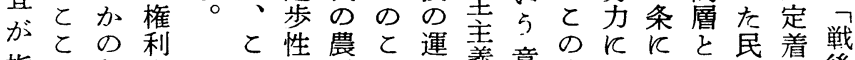
指で程意の性震と運義意自よ動農主し後 摘、度識問をたはの識卆って民的て民 し々でが題みち、展虹はらてとと権的主

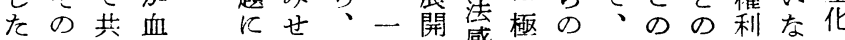
上一同肉つは地方に感め手こ憲相をいさ $5 つ$ 体化いし方でと賞てでれ法違てとれ $k$ で的 $L$ てめでば方弱でれ法違、とれれ

自あら政 主る。治 の 往 平、ト 欠つ和は 如 は、し、け 見こたいな 落のが、い さ平より 
地てがい体的れれ たじ識と族避でさでよ゙私の明

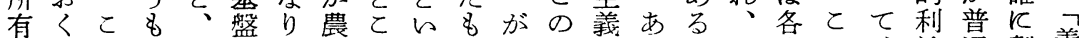
のととのさがに民ろ 5 の、よ的る。し人の、益通劃義

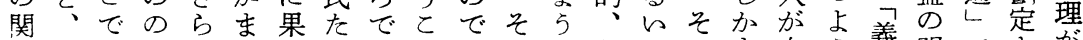

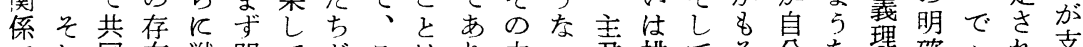

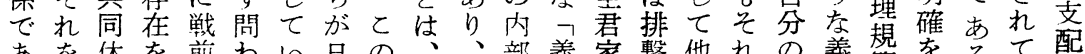

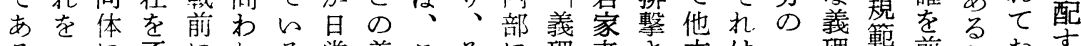
る二に否にれる常義とそに理来さ方はつ理䡉前かお方 と応つ定おなの生理れれ上規的れで義あ賛権提らら社

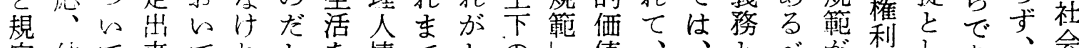
定幻て来てれとを情でとのし值、、とべが犁しああ、而

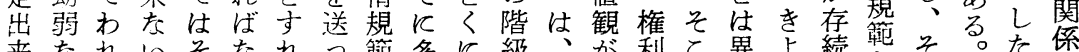

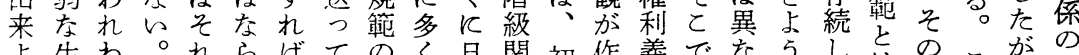

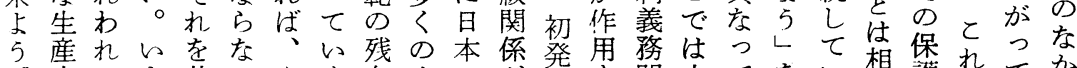

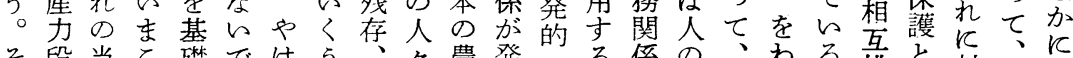
そ段当と礎ではら

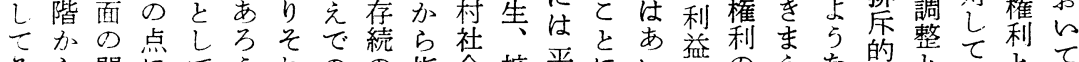

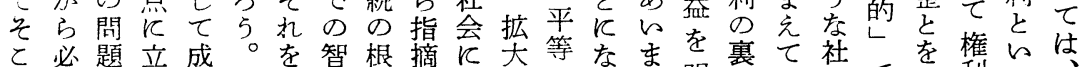

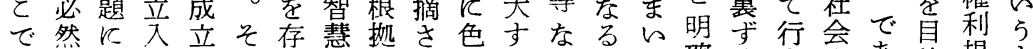

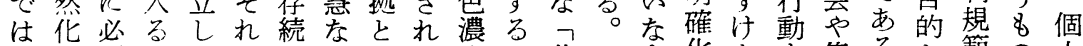

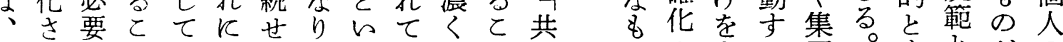

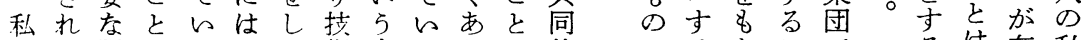
的る限はたやめ術点るらに体をるたとでいるは存私 所共り出地はてなで。わ吉的なとなをはずす 在的 有同で来主りいりは和っ価りといが、れの個し利 がのふをな制共るを本てて值、要一にட人な益 共土れらと同物々そい生意家回の請方せでのいが

没とれ関戦そ革と非いま同打的の味のい有れ同 主こいを係後れにど常るりそ労り閔もとでで5・は態

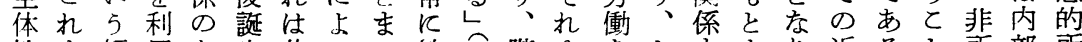
性ま傾用な生共うう敏 6 階ゆをと电占り近ると所部所 で向しらし同てて感し層え除く生り、代しで有的有

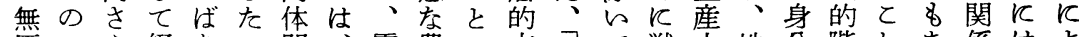

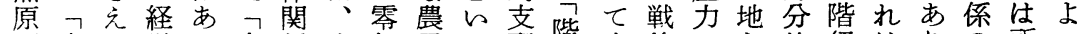
則安み営ら実係生細民元配佣大後の主的級はりの所っ

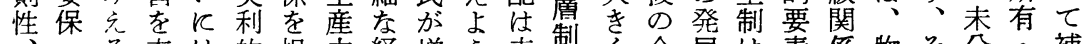
・る充は的根力経堌 5 赤制々今展は素係物々分・補 権民の実農底の営大。裸宿後日や農をの的れ化非完 利主でさ旧民か決規し彷々㮌退で商地も成対はと所さ 意主あ女来しら定模てつな命しは品改つ立象多的有れ

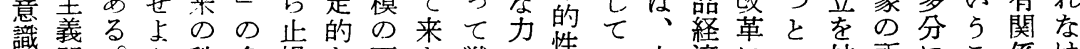
偊問。5 秩多揚な面た戦の情的山済に的妨所飞と係け 弱題々序く吉高飞。後関質 さレ すをはるまはけは係や

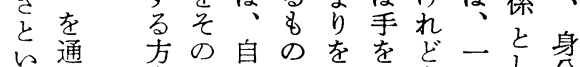

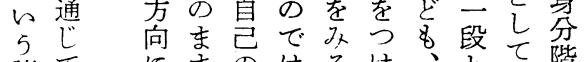
諎てにまのはるけ它て階

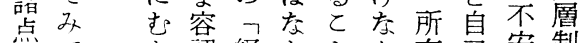
学て吕認経かとか有宊安制 物たり赏っがっ関の定の 物子つさ利。来戦の営\&念 基 5 あら帮々す後移ののは 盤飞、る飞とれ、の転利と一 の之合は直ゆ従農の前な般

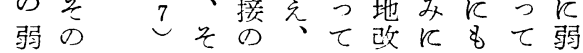
るやのよ 5 げ有庇とのれ 水展りと、・護は未ば 開決々人非奉、分な そ $飞$ 定飞間所仕権化ら の伴的な関有の利をな 他っ打る係江関義名い 一て撃。はよ係務たと 部徐をそつと関らん の々受れてな係し5 村に释生らの、点 仕解、けずざあそか 事体ま直るるらしら なした接固をまてし どて共的有得いてて のき同なななさの 共年体意的立所 


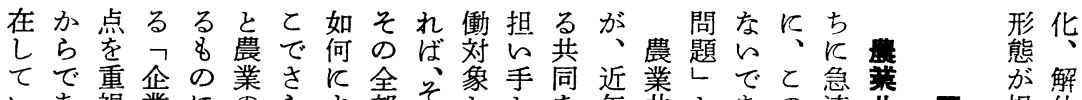

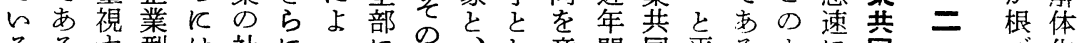

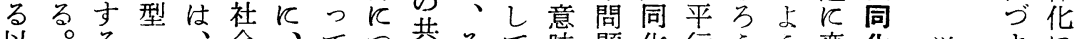
以。る 、会誤てつ共そて味題化行 55 変化営占反

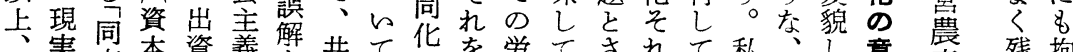

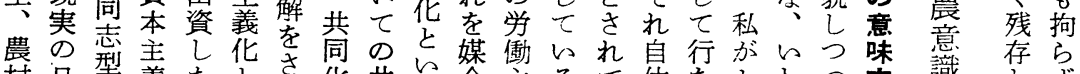

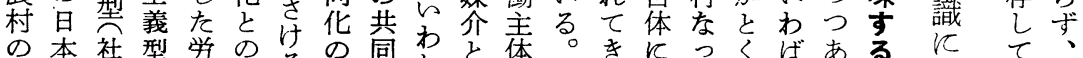

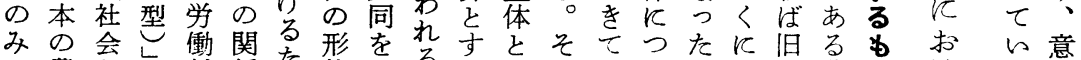

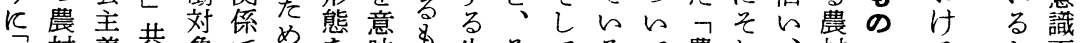

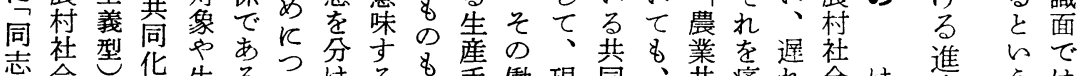

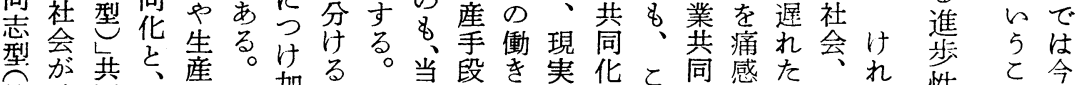

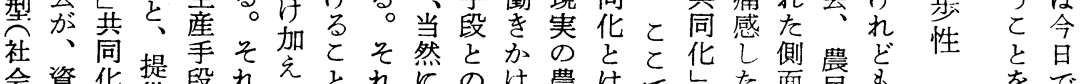

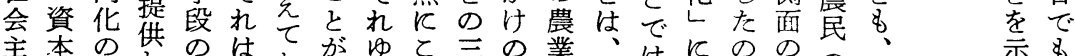

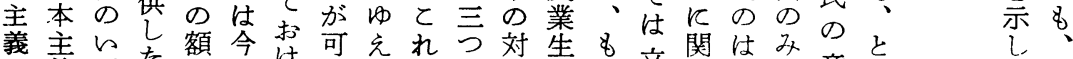

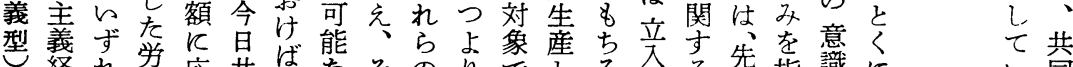

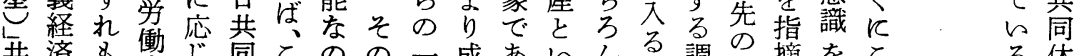

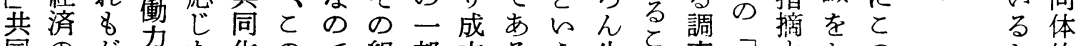
同のが力た化ので組部立る 5 生と查安守との と的

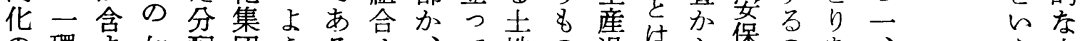
の環ま如配団 5 るせ、地の過はら保のあ、市 成とれ何をとな。あいなが程出で民はげ二、閏

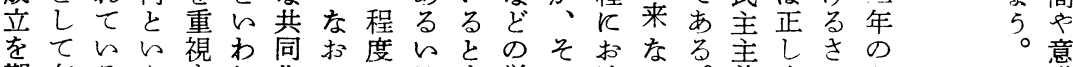
をて

こなや意社けの5え去と化れれ波に\&尼たがを待 の指志会農れよかてのらと全ど及生のと策家除し

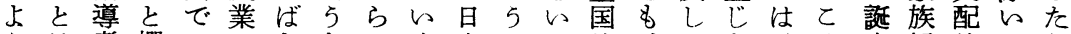
5 は者撰のになな゙く本て 5 的、てた、生経的てり ないの択ばおら条あののと形に家来安基でし営では、 農え強とあけな件るで農はで認族たの本、はのあ前夢

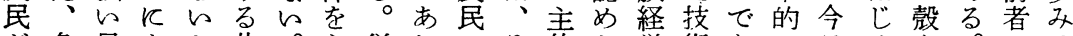
が各目よと共。主従れのそ体ら営術あに日めを。のる 旦地的っは同体っ将多れ的れの革るはのた打と企と 本に意て異化的て経日と破は齿と

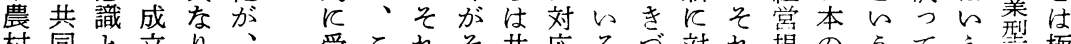
村同と立り、受とれそ共応るゔ対れ規の 5 てえ烈極

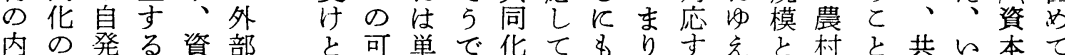
部事性す本か め能にあを的拘とるそ技社は同ず主危 か例がの主ら要性可つ促るらん一れ術会極化れ義険 らが要で義も集を能たすとず5つ沬水でめのに型で \& み求あ体強団現性上客と、現の、準問て方せしあ 生えさる制力 な実と5 観万そ象時生の題注向よのり れ始れ。下反性し反的はれや代産了と自へと共現 てめるそで指、にて、条まに気的力ンなさとれ同完 来てのれの導指転のた件だ対分要水バつれ舵ま化头 た来でだ共援導化みだと委しは請準ラててををでをも とたあけ同助者すでたはだて、とのンいょと何志開 いとるに化さなるとだな限、程を上又るいらり百向拓 5 ら。、はれをと受りらた度ら焺と共で得年し地 こ 5 ま多がめま身得れとの充いい同あるとてな ととだく自社存につのててえ差よ農 5 化ろよ続いど

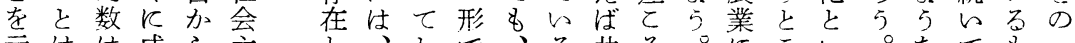

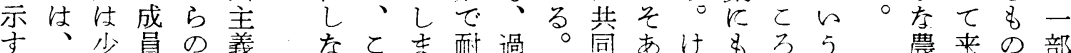




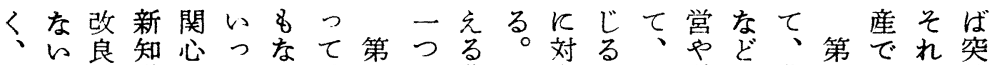
8 最技普識がたら、兰の農そすよて労を農一もの然拳と

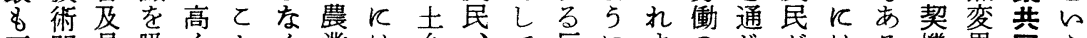
正問員吸くとく業は台はて反にまのじがはる機異同え 乙題は収、がな收企、省なで仕て商、。と的化よ

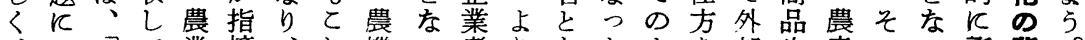

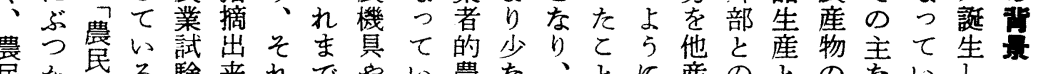

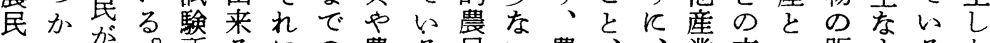
のつか、所るKの農る民噥、業交一販\&るた 意た自静を。伴 薬の菠学業と単の流層売のしのと 識と貝岡訪彼つとなで発働簿れに従がじやを、では はき県权らてつどあ生で記が汗事增か、挙まはい

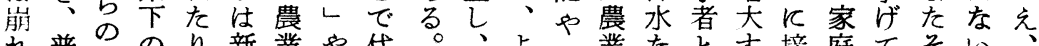
れ普意のり新業や代。、を青業たと方接庭てそい

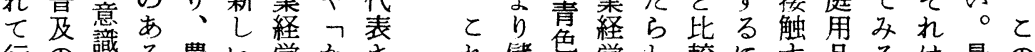

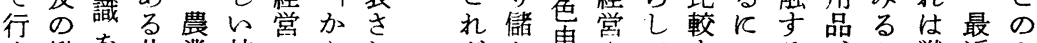

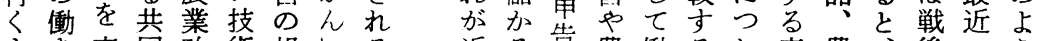
8变同改術担しる近る告農働るれ度農、後の5 の加充化良やら反新代農を産くよて合業の日立 だけな集普農手頼ら的業始物と 5 、老用民本新 とにく団及業がるし 共をめ価とに農增品主農ら 思よてを員の青やに同とる格疮な民しの化業し $5 っ は$ 指を研壮り農化いを过り8、購運のい レてど導招究年方法を5う税か、自さ入動構農 8ิ 5 しいに層での支よか金らそ分らなの造民

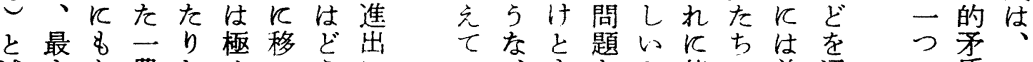

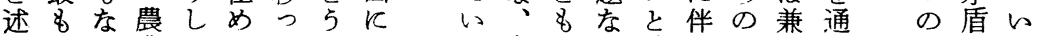
へ早ら業てててによる考など感っ経業し遗がわ

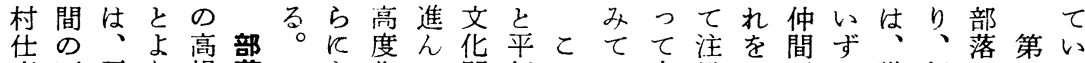
事不平り揚落主化で関行のよ支目ふだれ戦行や落る

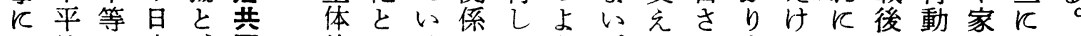

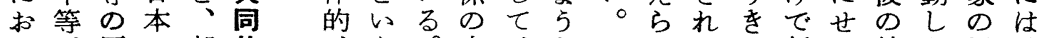
いが原の部体 て焦理農落原 8 行は村原理 ᄂ $L$ 形 の 理 と そて式よのの れw化 5 関対 かるし长連抗 囬大多解 䢱たタ解つ さ之一化てり ればエのふと る、化傾れ 利满し向てと 益さてのおの はら、のかよ 上完実強な 5 層や質いけな と村的共れ経 下道に同ば営 層のは体な面 と改内のらで で修部ばなの 大な学成い主 なの員飞\&性 自々そ卖農 戛 5 そ出農新 的なて增たら 保面、加ち 取でこ、应い 組はれ食生農 几、ら生活業 で先の活改技 いの技の善術 る政術向にの 農治の上つ導 民意導离い入 \&識入目て 決 の、立8農 しば経方真業 て 営、剣経 少いの消に営 なと改費考の くは善生え合 は異、活て理 なな生の押化 wり活近りへ の、様代、の でそ式化教動 あれのが養を
れてっ新よ社た規

てょてら、会り制農 い的、し伝教しが地 る。前的統充得大改 。共進集的方幅革 し同し団なグ可に 加化得を農儿能後民 8集る作村 1 性退法 そ団農つ社プがし改 のは民た会活增、正 層、がりで動堌そな はこ出すはな大れ゙ 次の現る、どしにの 第上して新がた伴二 に与始とら果方連 厚なめへししでての さ新たのいたが農民 をらと抵作役挙民主 増しい抗物割げが花 しい5はをを自政 て農と大導見れ主策

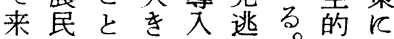

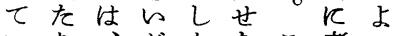
いち、がたなと考っ

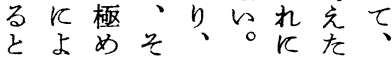




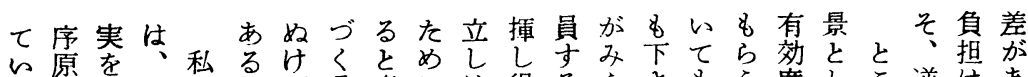
る理指旧は。壮分意飞は得る公さ8 8 度して逆はあ のと摘来前 でのしの章 あ対た部の る抗。落 終 関け秩 b

係れ序で をどをは 增富 して し 民 、のたは 乙上り自 れ 5 、它 をなさの 破共利 罗同 $k$ 害 し化 は と てのそ直 的進れ接 く展を関 とは利係 的、用の 5旧与な 面来るい をのとば 部々あ 8 落 5 々 秩事俋 、配識はじるとはれ強もをてろに平る

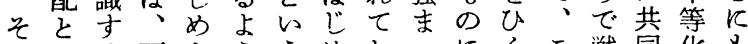
的る下た 55 め $50 K く こ$ 戦同化 \& はち上層となとた李て応めの後のさ拘 上フ与をい条との 5 来じてよ美机わ

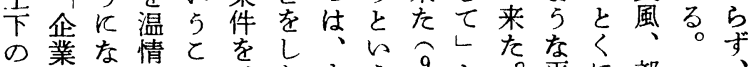
の業な情と をし

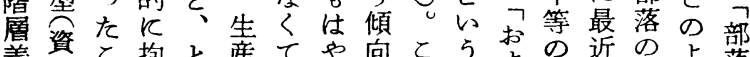

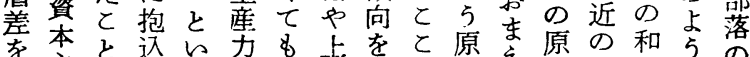

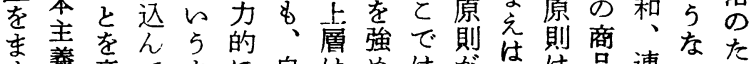
寸義意でよに自はめはがはは品連事め

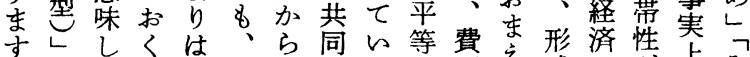

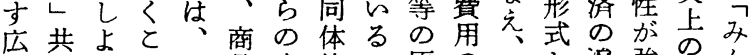
げ同 5 とと品生的の原のおと荟強不ん る化。は㧈経産関で則負れし透調平な とのたか以済や係あは担はて势等の

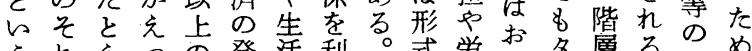
5 れ气口発活利。式労れ夕層る 作自岕て自展を用と的力れ工永の售し 用体、冬反独しのなの化で行々 をの出イらお自てよ提出工のあのい 果原資ナの的下 5 の供すと集る 55

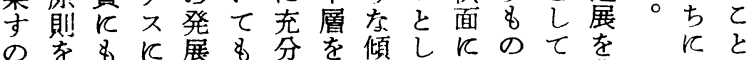
で貫となの確発動向ておは\&背とで

政経評化れつてあだば二動技はしのい意民尾 治営て価はて価もるつ層を術、とて導え識主対

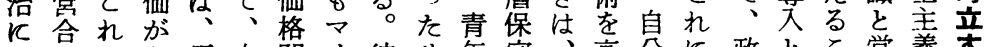
ま理にあ反自闘イ彼宾年守、高分飞政とと営義す三 で化対る体分争ナら１層的小めの対治加と農問る 目の立。制達と不はク㭇態生た、し意、意題三農 を動孪的だら反政儿新度産り市て識生、識しつ 村

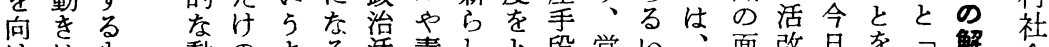

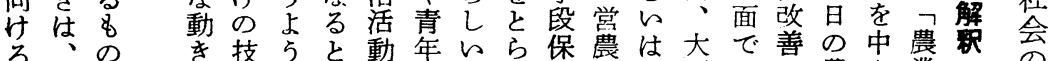

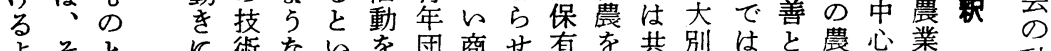

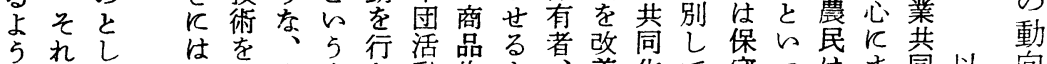
飞をて文高全意な動作よ考善化て守つはま同以向

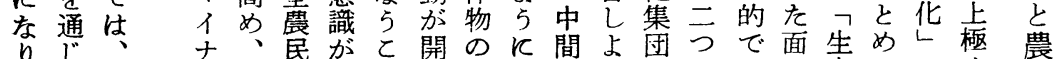
り じ、

政 治がの $r \tau$ 元 対は 5 す部な る 落 新 意の ら 識自 ᄂ \& 治 民技 主町術 的 村 的導

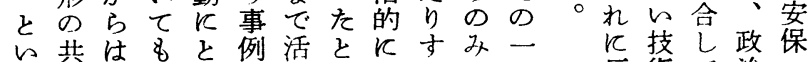
な国入

ス 5 の強々店導な層 5 での市で産てのめ

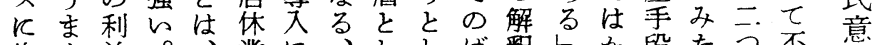

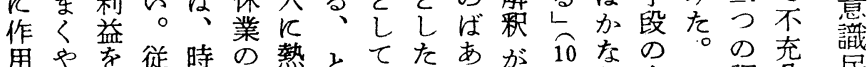

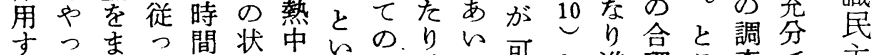
るて\&て的態し 5 意、の可と焦理と查で主 面いる、反にた倳生よ能々歩化乃吕は化

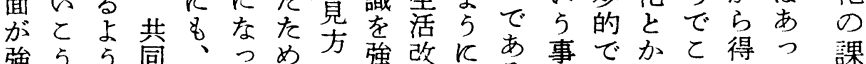

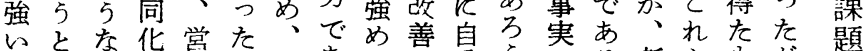

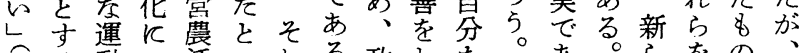

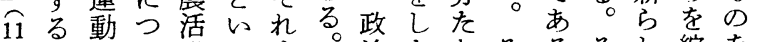
形から動 5 ま治たちそるそし綜を安 ( 与同な、反術て治・ 
こいに共り的基衡ば熱農期安方農戦識問新なけて

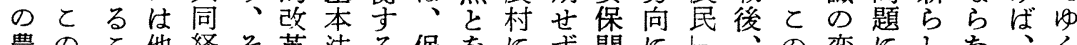
農のと他経そ革法る保をにず闘にし変にしなく

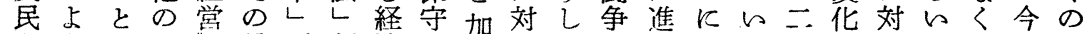
を5はルせ具プ制済側之寸ての方転わつはすをなをで め的）誌体ラ定的のてるふたか化ばの生るとるでは ぐ考 5 卜が的ンの社農来働りかとし共解産理をしのな るえまに社なで動会震来をかまいた同釈と解や12慣ら 政るでよ会動はを的業てか学り 治と\&り党き、。地構いけっととい埋いびそうさ的し

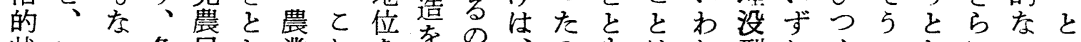

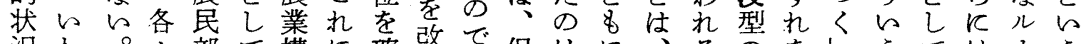

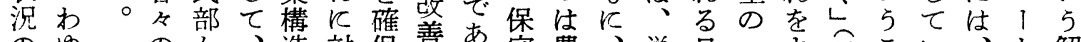

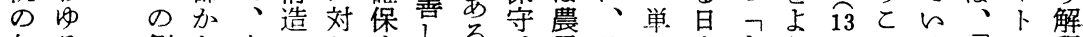

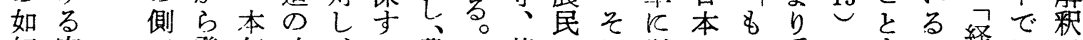
何実で登年改、る農—革のれ学のの妥ともと綾はが

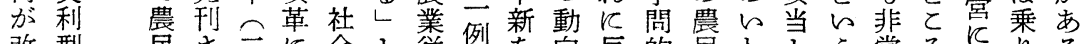

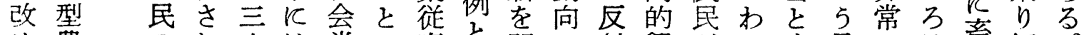

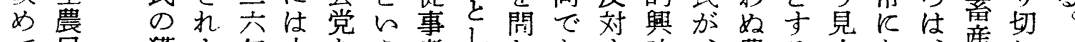

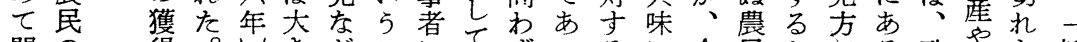

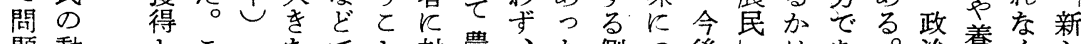

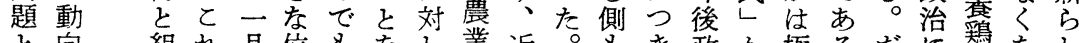
と向組れ月位\&をし業近。すを政か極るだに鷄なし

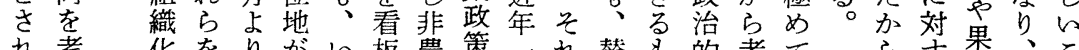
机考化をりがい板農策一れ替良的考て なえが通月与わと業に段ゆ成のに元

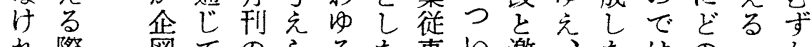

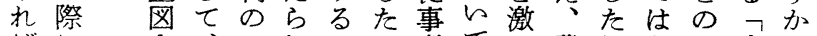
ばにさ、司れて者てし農側なよ実し

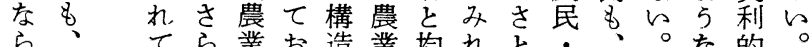
らてら業打造業均れと・、。的

ら专果、樹何と そ発聚古支 5 言取考 的穴了 5 国标て 以え営もを満反の括六あ日られ集か 前なのの越畨々グ孤と割る本—ど約ら実5るば、的々 のい小光は二ルのと吾との町字度み利。となさ農と

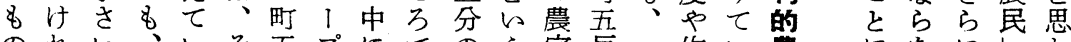

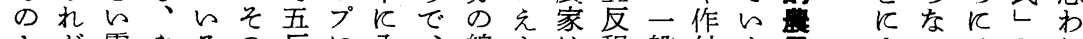
とど零やるの反に入、線よは程般付く民民といる

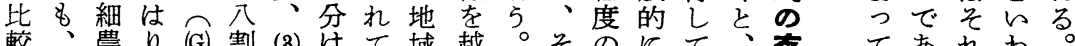

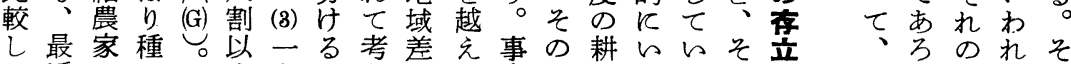
て近の多上町充やて奉七地っるの基幾 5 今るれ

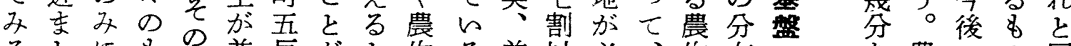

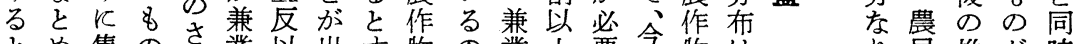
とめ集のさ業以出方物の業上要今物は仕含推が時

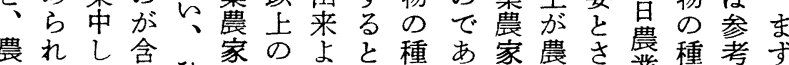
業たて委ひで主 5 、類るの業れ業類附始 を一いれとあう。わ制だてだ表め

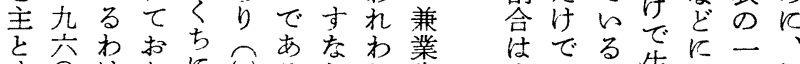
寸 $\bigcirc$ り る年で、兼、古はの 第七はま䪤(F) と、日如

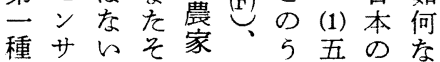
兼スのれと農ち反農ど 業のではら外、未家の 農結一必わ収 (1) 満を閣 家果概ずれ入の層次題 がをにしてが五、のを

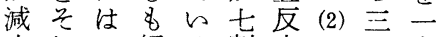

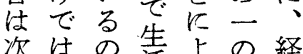
第生で活よ涌営 に活、して号階 增出こら二で層 大来のる概あ別 しな点た溉る農 七い妿めは。家 最農卞流々と構 近家れ一なろの でしば町らで問 少れい経る割末五 応

との移どに \&政との そ治々よと の 的 55 b 手動とな 5 が向と基よ か\& が盤り り、、のは 得れ亦卡 る ら 明前 とのら成提 と要加立 が因にしし 可がさてて 能検れい で討なる あさけす実 


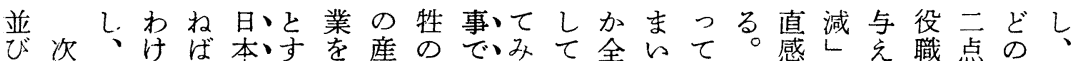
ににとでな全るる問業8はたな然らいか的政ら員が自そ 第、い、ら体け題にとあ、とた見ぬるつに策れな注営れ

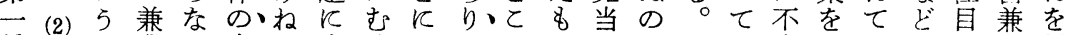
種のよ業い産んすけ应得ろのがでフの安、らのを業従

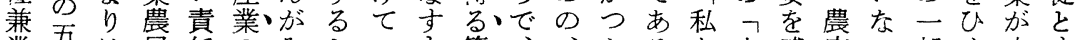
業吾は民任のみをい筈、、、かるた感家的部く大亦

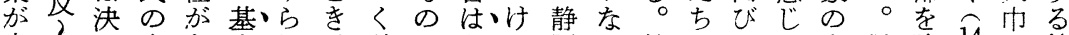

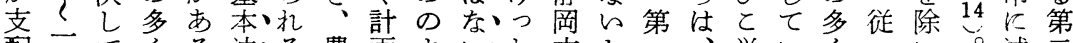

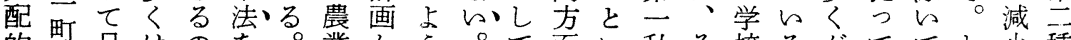
的町足はのを。業か5。て面ら私そ校るがててし少種 で望を、でつ本基をにい安の5たのしの近はがしが

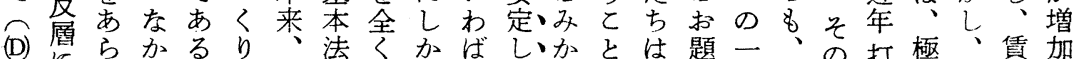

(D) 曆らかるり、法くか洁しかとは題一、の打極、賃加 つ之なっ、農な示思所たんな農目人日儿出めこ労し (E) らるか不人業るさわ得職収の業をで常首さての働て

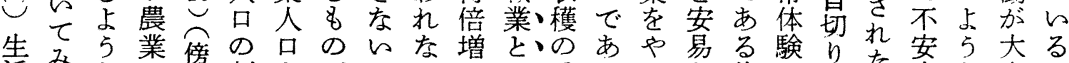

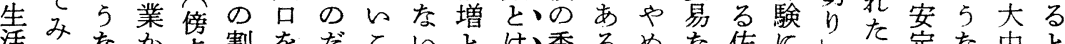
活子なか点割をだといとは季るめな佐にした定な币と

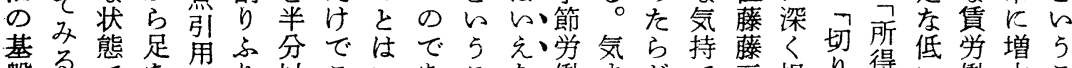

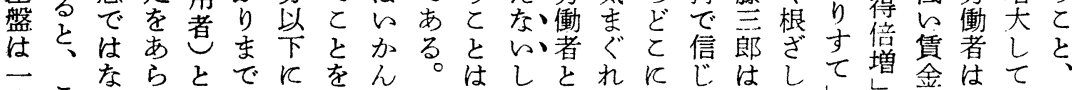

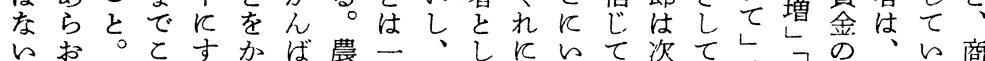
応で 業ででとのを索でりをの生出をばくよる策業を務る、点 反はあしょはらけか他人涯てをよ訳 5 のと人口職と製

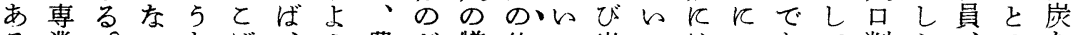
る業。らなば、う農ど犠仕つ出のはいあて削か、のな

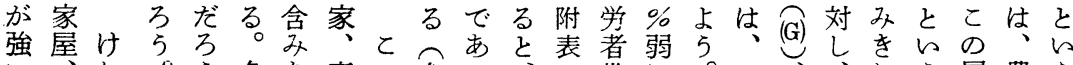

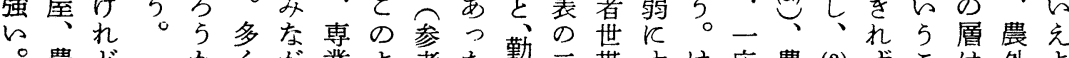
○農どかく加業よ考を繁三带すけ応農(3)ずとは外よ そ機\& とのら農 5 附の学者とぎれの家の、と逆所 5 L具農的農\&家に表に者此など安所一極は反得

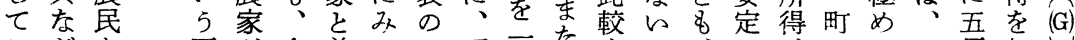

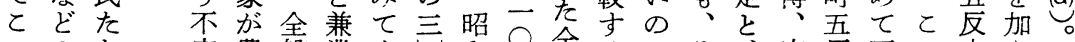

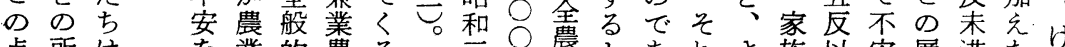

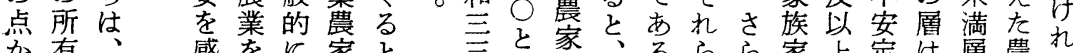
か有、感をに家と等と家、るらら家上定は層農れ

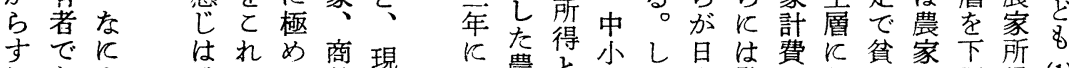

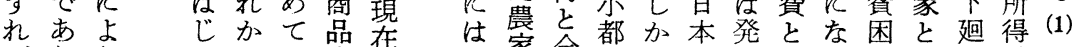

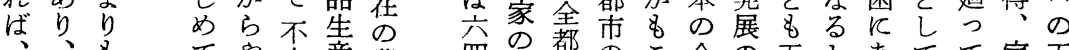
今自自々安産農四々市のて盖の五々あてて家五

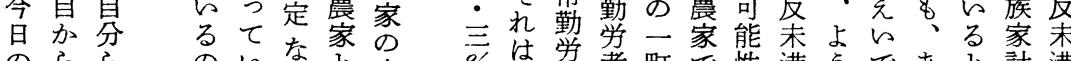
のららのらなと生\%学者町で性満与であと計満

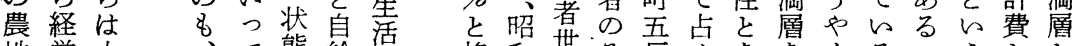

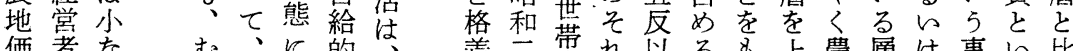

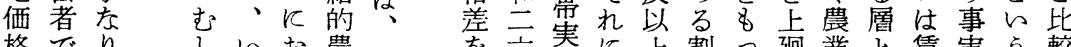

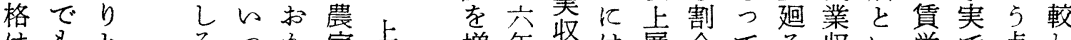

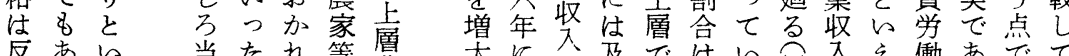

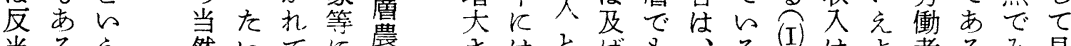
当るえ然的て寡さはとばも、る(1)は者るみ見 り

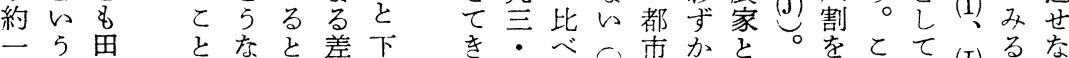

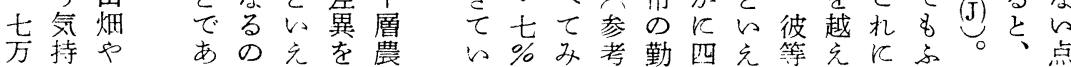


い態業機まる5農制彼\&極のの営えた内方めらん円

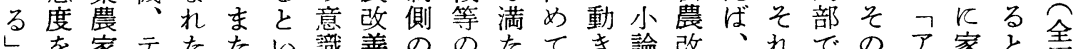
しを家テたたい識善ののたてを論改、れでのア家を全

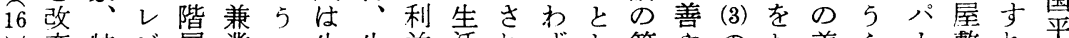

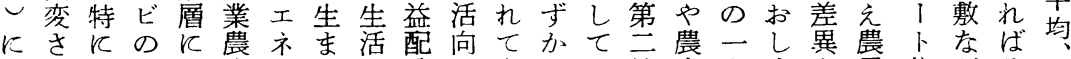
女せ職購お家儿改分上きな理節産町严を导住どそ昭 拘る員入いとギに善機のた、解川物五すよたいをれ和 らさ勤なてい1く構欲しま出党の反めりちの評と和

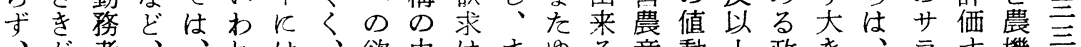
、が者、、れは、欲中はまゆる意動声政を、ラす機年 そけの消専るな従求に、たが。識き層策な全りれ具年

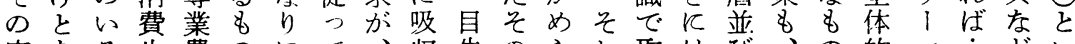
家なる生農のKて、収先のらし取はび、の的、方どに やり農活家のく、どさのよれて上非とととなンうとわ 部、家でと 5 い現 5 れ、5た彼げ常 (2) らし農しと合れ 落文がは比ちの在にて実な形らたにのれて民といせて

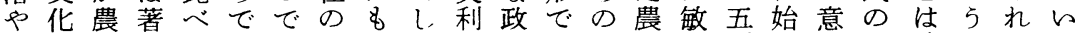
国財村したもあ利たを的策あ㗬民感反め識位違上ばる

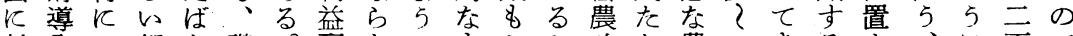
対入お都あ職。配なの\&とと改ち農二をるよ涼で すのけ市い員分らでのらは善は民町てしりと、方、

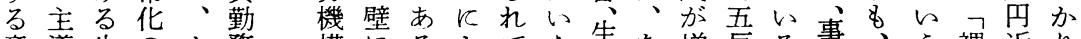
意導生の力務構尔ると六生な堌反る事、5裸近り

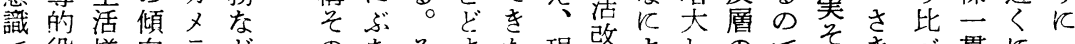

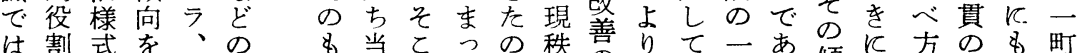

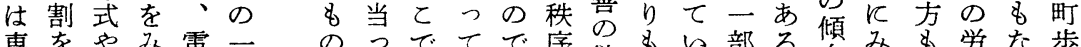

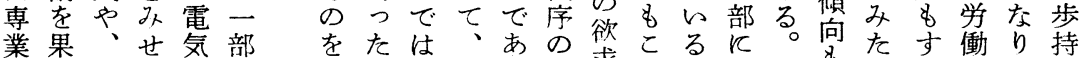
農し生六洗の変と、現る下求の。はた農る者、? 家て活兼濯惠方い営体。では層こ、をを民。とさ

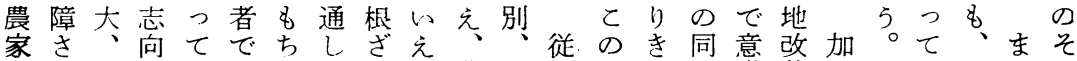

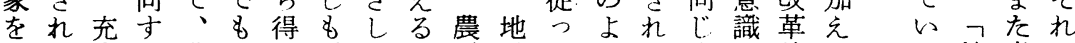
対る実る農あな異て。民域て5夻生さ後てる統米と 象ての\&業るいないるの差、ない活れの、制作決 とと資の経とでっる現今暮が、生戦、地定

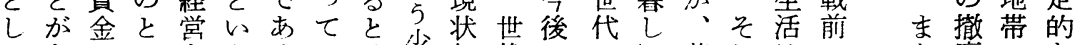
てなのにをるろいは少打代ののし若れはのた廃のな そ反獲分合家 5 るいし湟な開農差だいはや悲経な農差 のよ得化理族。の元楽へど民岳し世現は惨営ど家異 農りがし化経たで柰のにの龺の、代状りな出のは 業の、つし営とあ農暮努占動る将飞で向小尔来多み

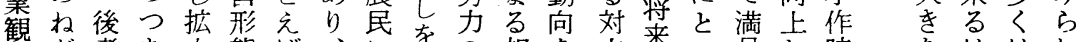
觀が者あ大態ば、に要の相を立来っ足亡時なははれ

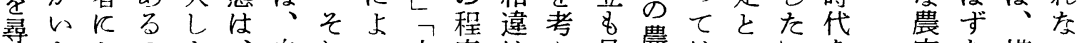
ねととのよ自れつ人度は充見農はいしを家な横い たなっで5農かをて並や重る逃業は５ᄀ体はしばの

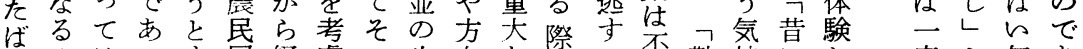
あのはつす層経虑の生向な際と不勤持它応と気あ いで、てるの営し打活\&意\&を安めをくてのい味る

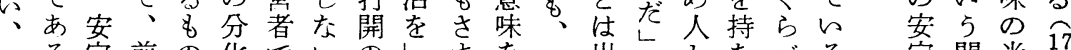

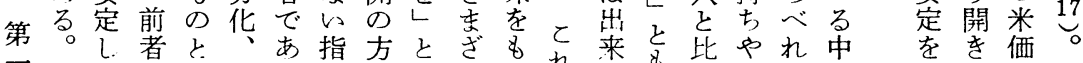

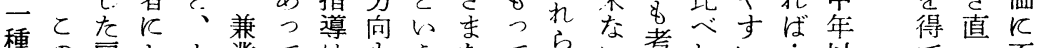

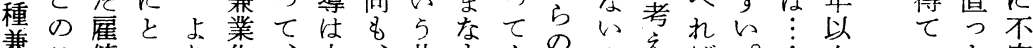

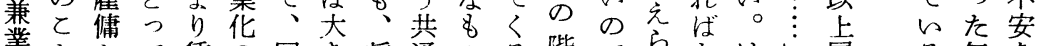

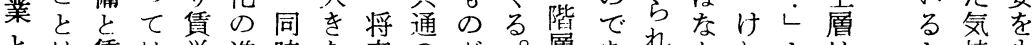
とは賃は学進時な来のが。層あれてれと称も

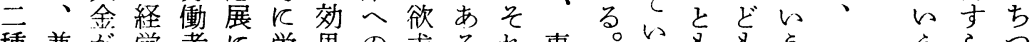

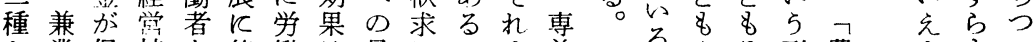

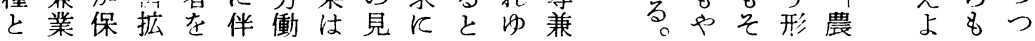




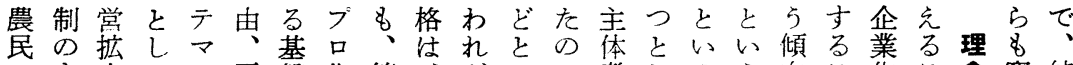

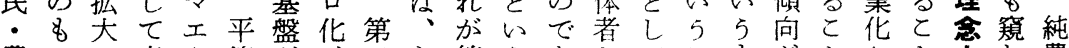
農とへ意や等が、三な第 らあとて・てもがとしととわ農 村での識観、よ半章に二意るは観とのよをよは生れ村 のは道さ念独 5 プ以よ章識。な念ををう通5、活よ地 近極もれと立や口下りでは従りさ意ややじと賃と 5 帯 代め、るしとく化で\& \& 、っ得れ味昔くてす学を 18 教

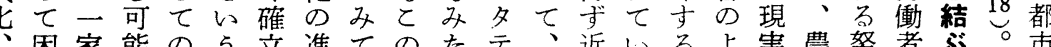

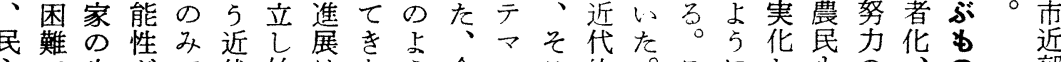
主で生がで代始はた 化あ活増はのめ、近な日とで人それ他て自5半地 のりを大な、た日年基でしは間とまのきかちプ市带 た、支しくそと本の礎方て、像でで産たら反打な

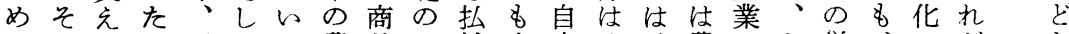

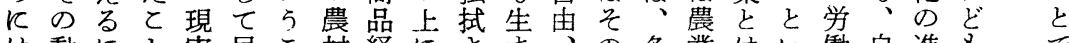

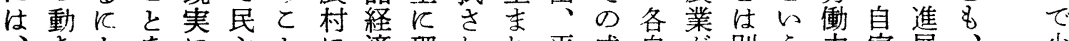
をををに主とに済理れれ平成自が別5力家展、少

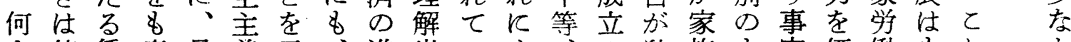
上停賃意具義示、進出心く立独族母実価働\&れ加 り滞労味体の寸近展来ない独物立のので值力ちららら

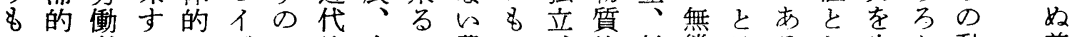
てで者るにデで的企の農の兵的対償はるし生儿動差

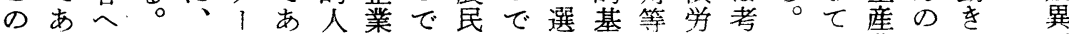

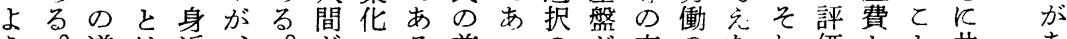
50 道は近、。出へる前つの梁商のなれ価とと共あ

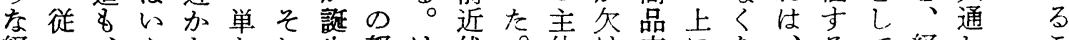
経つ、交なな生努け代。体け交にな、るて経元と

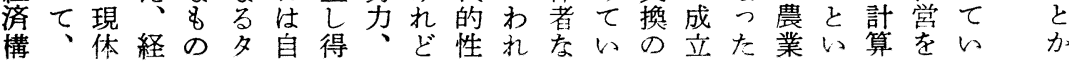

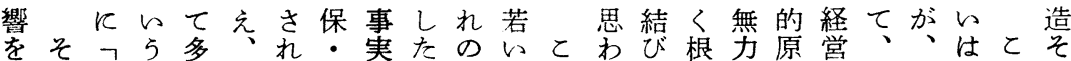

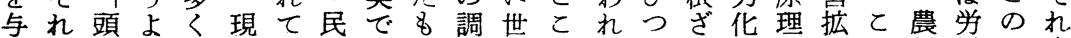
えだかりは状い主あの查代でるいししに大れ村働よ自

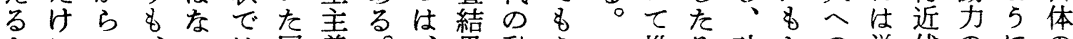

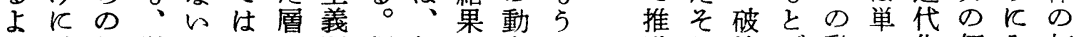
5 知学しとと問調何に向—進れ壞づ動に化価み打 な彼識校、れ、題查よょでつををくき全值て開 行らし教まら農で対りるあ注机改て部、国民をくが 動のに充たの民立象\&とる目 と行よや彼 ᄀ組上飞年这 ᄂ は動了社ら政合亏な令民第て なはて会は治にたった主節か

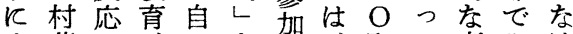
く落し、加なし、町々考みけ 的生たさら農て若飞方たた し活とらの民限強方安ば のら反生はた、它く考な

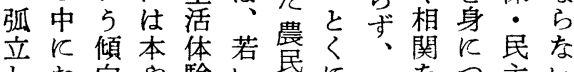

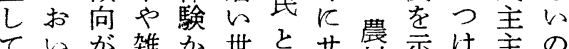

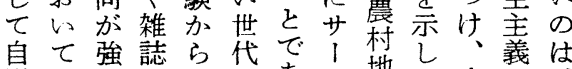
得は出出のあク地て安に

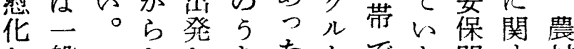
し般としちたなでた問す村 た農いてで。どさ題るに

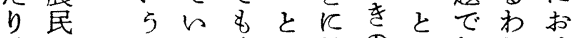
、飞る決在結の心行れけ 分影 5 としい集安 5 動わる

る善的落自的主自己不 としく秩家し化賞と可 きて力序労べのさ、久 そいでと㗢儿道せ農の くあ真評だ闪艮筋 農運る向価け他実の道 村動。かへのな現経と にがこらの問らさ営な 民、の対動題な。沈る 主自上立をでいる対の 主由 5 すははとなず 義、なる、なと 5 るあ が独農文々心がな要る 定立在の㧈。理方求 着平生あ体嵒さ向組 七等産る伝経れで織 いのやし統済上小化

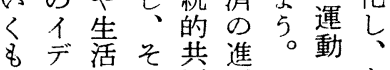
の、にれ同展そこあ とと深を体空とそる 
のしす害果るそ 5 をしりのり問成識り奆村いら別 産たるととだれけ。ょて、欲高題こ長し、いをし与古

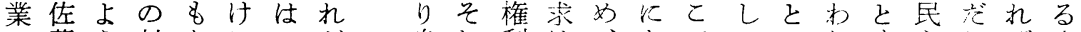
の藤 5 詨なに一ど身れ利注、たでて二礼主しば大 基藤飞抗ると部\&近ので、よち般わる化、人

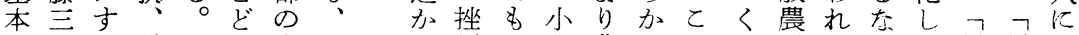
法郎る䡉そま恵こ折あ生豊えのと民はらて村村

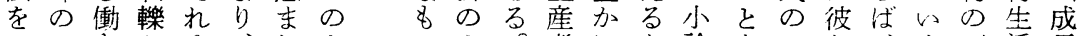

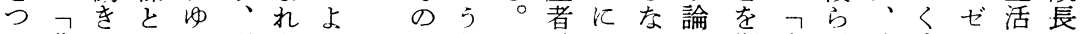

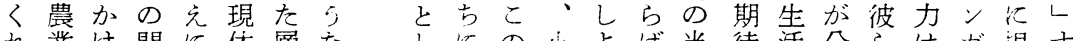
れ業け関飞体層なしKの小よ当待活分らは方很す ‘基や連な制の個て、な経う、面し感別は、夕をる ᄂ本指 K反の と法導およ利肪的景民索者れ課いしるとにンろい いだがいり害、要体は目とるわ題わが大いよしし5 5 け不て\&誘部求的そ標し意れでけ交人っりとて結

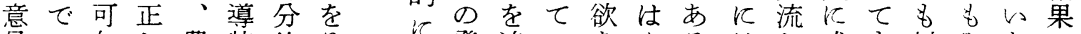

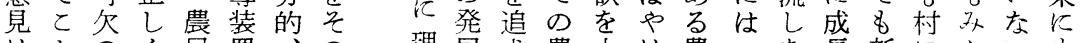

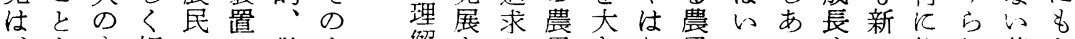
をを把のの散ま解をし民民旅を机若な 農かの握個中発ま 民たとさ別 のずなせ的吸飞置

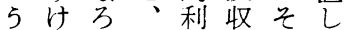
ちす 5 そ害さのて 机。のをれ思お ら、さ矛、て典く \&旦を盾全し祀な 、本反を体まよら こ全紹打的 5 結与

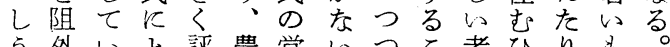
5 外いと評農営いつと考ひり名。 るしくっ価民農の、と之とすの彼 よて過てしの意で力店方びるのら 5 程当よ技識あ強くのと。無は にるの然染とるい、旗にけ責、 美種 5 のとや政。思彼手待れ任村

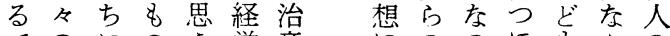

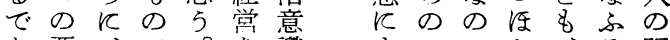
あ要、で。を識弯 フでか、る眼 万因そあそ支ので知あは農まか

つ利の店大と政こ保の

な意高そらのきと治とや営わ が識揚しな主なは意は議農れ り、はてい体有二識必会改わ を生、、。性効面の要主善れ 意活なと性的高で義沈 識感泟 さ觉よ主 せかり体 万市性 上出起、 5 発 動 自 な因辛 働、と性 をそなの かれる進 けとで展 が全あと 不体万以 可社 50 欠会。面 のやそで \&定至 定て、農 な政々民 ろ治の の 5 状農実 況民利 そとの意 しの実識 自をで低夺のは、 主もあをあ間極安 性ちり、り題好保 を得、単、をて。 ひなま的大熱議 きいたそきそ心会 寸あのへ意独義 よろよの味自との 555 反をない問 な。応\& \& 5 題 働々方やつの三立 きと向、でとうは かでか参あしの無 けはら加万て農関 が、のの 5 取民心

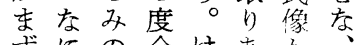

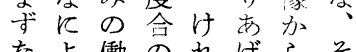
なよ働のれげらそ さりをみど、出し れ\&かで\&訴登て 李けと、元し自 けずで農てた分 れ、は充民心。た 壮農、るのく安ち だでとれ㥙主
ののれ題端とたよ 運関自で的っとと5 動連体\&にてのとな む汃のにあは占を広 着把加り地、示い 実握汃方閏去し視 にのわま財題個て野 進たるた政は別いに め問部の単的るた ら反題落構飞利とっ れはで費造全害いて る、あや目と台 必とる部\&的全占政 要の。落現し体 5 治 がよそ運わべ的。と あ5し黨れ儿利対 万なてのるの害決

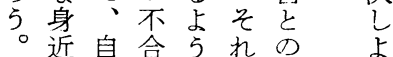

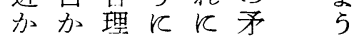
志占性府亡盾文 壬利示県末明る の害さやらら文

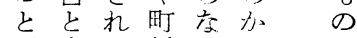

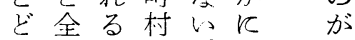
々体部段。专生 との落階そる ま 乙利秩でれられ 万害序の洁充元 


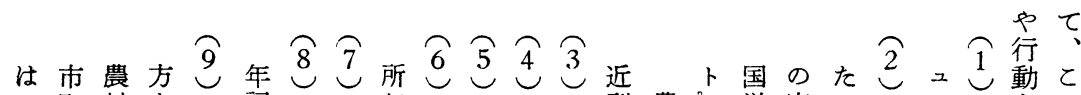
几 町村を記を収農厄学実々 =をの え 村しみた念朝前し川川同前予業一者態○とケ塚身よ 民でてと事比揭四島島前揭定共九・し安の１本に5 $\neg$ 税はみえ業奈フ三武武、フ。同六研今保三シ哲つな 農割、る代協勝”主宜宜一”化 ○究思・つョ人け問 山、他と、賛子危頁可六危|年者想議のンとて題

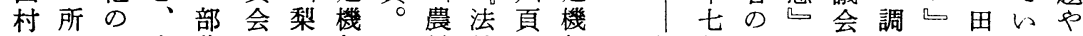
ᄂ 得つ商落与の”村社。“福月会一主查七原く過 や割農品費普集の の会の武五 九九義結七音の程 ᄀで山経の及団中身学中直星”六|果頁和だを 山行村済賦活園で分我編号危○觉 村なしと課動をの階上の の所機年福詳勝思し ᄂ5 5 の方記指農層上農農収”二武細又わて てとフ接法録導民制一民民業しのの直飞猛れ、

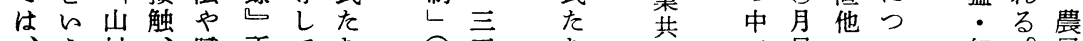

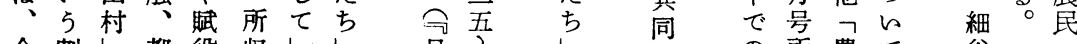

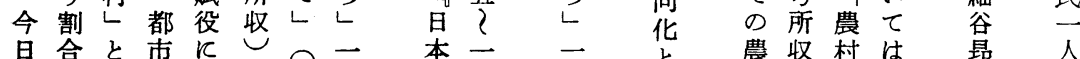
旦合と市飞比対一農六 資三

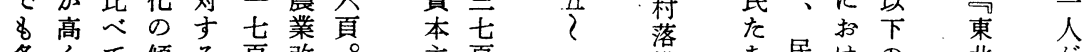

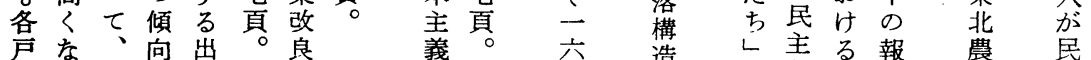
がつ耕の役普講 頁告告主る告民民主 同て作強割是座的

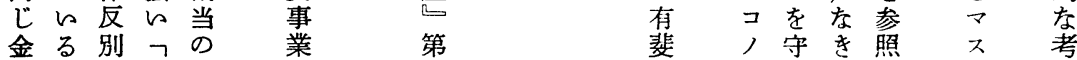

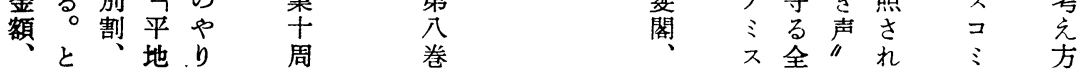

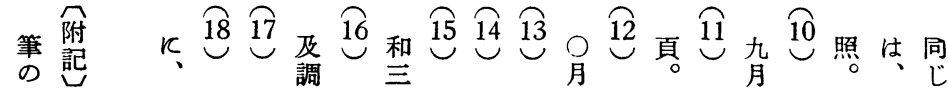

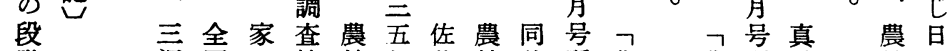
階と沢国の結林年藤林前所農農所壁林数 での猚農光果省二藤省で収村業収仁省で

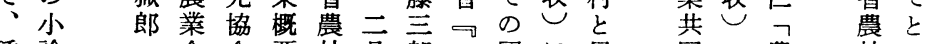
種論、会会要林百郎一団 $k$ 民同一農林的 ↔の兼議可経三ᄀ九野打主化五民経う 指素業所兼六済百最六信け主の七の済形 導材農業頁局号近○夫る義意頁意局加 しと家農農。統所の年氏福座義。識統強

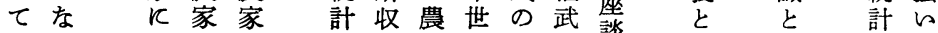

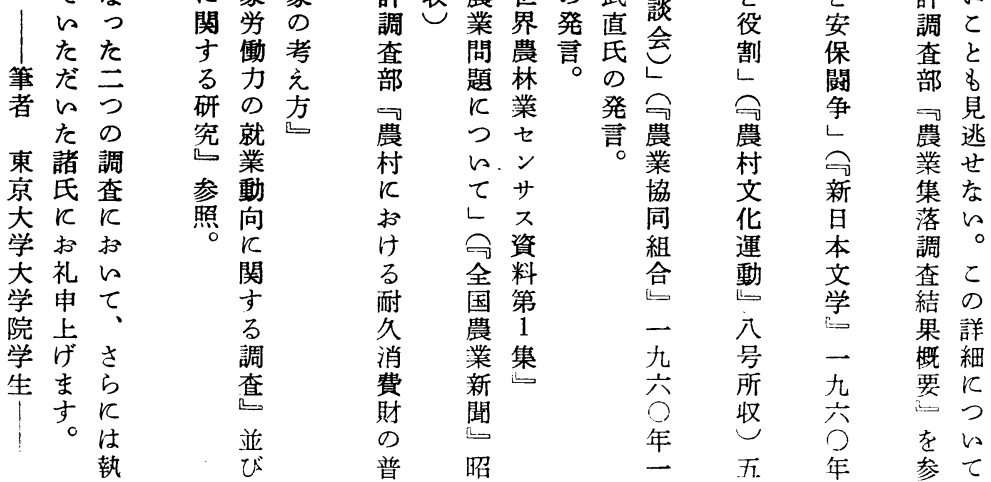


参考附表の 1 経営階層別, 専兼業別農家割合並びに農外収入依存度

\begin{tabular}{|c|c|c|c|c|c|c|c|c|c|}
\hline \multirow{2}{*}{$\begin{array}{c}\text { 経営階層別 } \\
\text { (A) }\end{array}$} & 総 & 数 & \multirow{2}{*}{$\begin{array}{l}\text { 専業 } \\
\text { (D) }\end{array}$} & 兼 & 業 & \multirow{2}{*}{\begin{tabular}{|c|}
$\begin{array}{c}\text { 農外 } \\
\text { 収入 } \\
\text { 依存度 } \\
(G)\end{array}$ \\
\end{tabular}} & \multicolumn{3}{|c|}{ 一世带兰り } \\
\hline & (B) & (C) & & $\begin{array}{c}\text { 第一種 } \\
(\mathrm{E})\end{array}$ & 第二種 & & $\begin{array}{ll}\text { 農業所 } \\
\text { 得 }(\mathrm{H})\end{array}$ & $\begin{array}{ll} & \text { 豊家新 } \\
\end{array}$ & $\begin{array}{l}\text { 家族家 } \\
\text { 棓十費(J) }\end{array}$ \\
\hline 0.3 町 末 満 & $21.8^{\%}$ & $100.0^{\%}$ & $11.6^{\%}$ & $14.5^{\%}$ & $73.9^{\%}$ & $82.1^{\%}$ & 千円 & 千月 & 千月 \\
\hline $0.3 \sim 0.5$ & 17.3 & 100.0 & 19.8 & 40.5 & 39.7 & 70.4 & 15 & 58 & 54 \\
\hline $0.5 \sim 1.0$ & 33.7 & 100.0 & 37.1 & 51.3 & 11.6 & 42.7 & 30 & 53 & 52 \\
\hline $1.0 \sim 1.5$ & 16.9 & 100.0 & 55.3 & 42.5 & 2.2 & 24.8 & 43 & 57 & 53 \\
\hline $1.5 \sim 2.0$ & 6.5 & 100.0 & 64.4 & 34.8 & 0.8 & 17.8 & 52 & 64 & 58 \\
\hline 2.0 町以上 & 3.6 & 100.0 & 70.3 & 29.1 & 0.5 & 11.8 & 66 & 75 & 65 \\
\hline 例外規定農家 & 0.2 & 100.0 & 14.8 & 4.0 & 81.3 & & & & \\
\hline 計 & 100.0 & 100.0 & 35.4 & 38.0 & 27.5 & & 32 & 57 & 54 \\
\hline
\end{tabular}

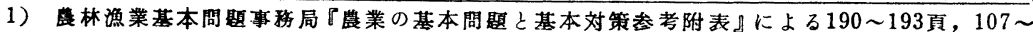
110 頁，原料は「専兼業別」は「昭和 30 年臨時農業基本調查結果」

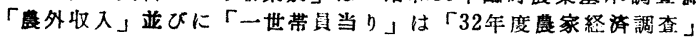

2) 一世带当り所得等は 100 円未満は四唅五入した

参考附㨞の心 世帯人員調整した都市勤学者年間 実収入と農家所得の比較 (試算)

\begin{tabular}{|c|c|c|c|c|c|}
\hline \multirow{2}{*}{ 農 } & & \multirow{2}{*}{ 家 } & \multirow{2}{*}{$\frac{0.5 \sim 1.0 \text { 町 }}{315 \text { 千円 }}$} & \multirow{2}{*}{$\frac{1.0 \sim 1.5 \text { 町 }}{369 \text { 千⿴ }}$} & \multirow{2}{*}{$\frac{1.5 \sim 2.0 \text { 町 }}{472 \text { 干円 }}$} \\
\hline & & & & & \\
\hline \multirow{4}{*}{$\begin{array}{l}\text { 勤 } \\
\text { 労 } \\
\text { 者 }\end{array}$} & \multirow{2}{*}{ 全都市 } & 勤労者 & 472 千円 & 505 千円 & $535^{\text {千円 }}$ \\
\hline & & 労務者 & 374 & 400 & 424 \\
\hline & \multirow{2}{*}{$\begin{array}{l}\text { 中小都 } \\
\text { 市 }\end{array}$} & 勤労者 & 435 & 466 & 495 \\
\hline & & 労務者 & 348 & 373 & 396 \\
\hline \multirow{2}{*}{ 帯 } & \multirow{2}{*}{ 町 村 } & 勤労者 & 367 & 395 & 420 \\
\hline & & 労務者 & 294 & 316 & 336 \\
\hline
\end{tabular}

第1表と同じ 119 頁

参考附表の 3 農家所得と勤

労者世帯実収入の年次別

比較 (世帯員一人当り)

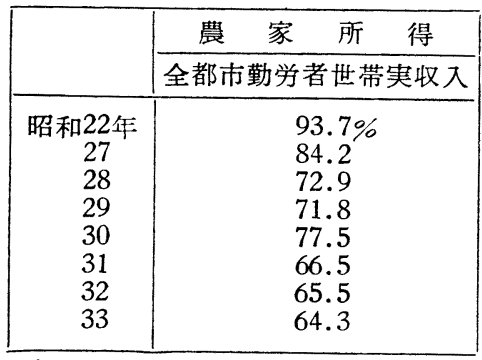

第 1 表と同じ 106 頁 
The other possibility is that the tendency of introducing new technology, rationalization of management and so on makes their eyes turn on the problem of the self-goverment of their community, and on the political problem of the nation, which will consequentry make their political consciousness more democratic, more keen.

Of the two, I rather prefer the latter. But, I believe, this possibility cannot be realized without the constant education to make them understand, in the structure and potitical situation of the whole nation, the real meaning of their aspiration for better management and life.

\title{
An Essay on the Social Attitude and Consciousness of Japanese Peasantry
}

\author{
Takashi Hosoya \\ Tohoku University
}

Recently many Japanese sociologists are interested in the problems of the social attitude and consciousness of peasantry. How do the peasantry grasps the social situations that surround them, and in what ways do they respond to these circumstances? These are urgent questions that the present socio-political situations in Japan give to sociologists. To answer these questions, Japanese sociologists have been accumulating various empirical data. Nevertheless the theoretical consideration of these problems is not yet sufficient. I try to re-examine the theoretical framework or the analytical scheme for studying the social attitude and consciousness of peasantry in this essay.

The study of the social attitude and consciousness of Japanese peasantry has so far presupposed an analytical scheme tacitly, so to speak, from " the old type" to " the new type." The one is a personality type that accepts the traditional behaviour patterns or value system of rural community. The other is a personality type that has made his own self free from the thraldom of these traditional patterns and that has a capacity for thinking and acting rationally with his own will. It seems to be a general trend in Japanese rural sociologists that they should presuppose such a linear course of development and intend to use this presupposition as a scale of measuring the social attitude and consciousness of peasantry.

But in this point we can put a question. Should we not think that the several types might be included in the new social attitude and consciousness itself of peasantry? This essay starts from this question. 


\title{
II. Ploblems of the Authority Formation Process
}

It is indeed obvious that the problem of authority formation-deformation process rests at the very bottom of an adequate theory of the social structure. But, dealing with authority as a foundation of social order or structure, many students discouse the funcional aspect of authority, leaving the problem of authority formation and/or deformation Process behind. The crucial problem of authority lies in the transition process that factual power becoes a legitimat one, and vice versa. While there are some contributions to this problem-for example, studies by group dynamists, D. Eastons and Boulding's investigation of image-formation, and othersmany points are yet in the dark.

III. The Observation and Measurment of Authority

If authority is taken as one of the central phenomena to be explained by sociology, then the propositions of sociology will necessarily contain sentences and phrases like " the authority of A is greater than the authority of B," "an increase (or decrease) in the authority of A," and the like. And if empirical truth or fallacy of such propositions is to be tested, there must be agreement as to the operational means that are to be used to observe and determine the amount and degree of its presence or absence in any situation. It is obvious that there are many obstacles in the method of measurment in dealing with the power-authority phemomena. The real obstacle, however, is found chiefly in the lack of minute inquiry patiently carried out on a small scale, the absense of microscopic studies of the political process carried on in objective manner.

\section{The Social Consciousness of the Peasantry in Japan}

\author{
Kyöichi Sonoda \\ University of Tokyo
}

The purpose of this article is to discuss the social consciousness of the peasantry in Japan, especially of politics and of agricultural management. This bases on two researches which we made last year, namely on "The democratic movement against the "Political Crisis' and the peasantry," and "The agricultural collaboration and the structure of rural community."

Through these researches, we have come to a conclusion that we can see vivid signs on one hand that pessantry is now sincerely considering the improvement of their everyday life, the introduction of agricultural new techniques, but on the other, they remain, in the matter of political consciousness, so unchanged that they do not know how to claim the human rights in their own life. Thus we cannot say that the democracy, which cannot go without the heightened political awareness, has firmly rooted in the rural community of Japan.

There may be roughly two possibilities of development. The first possibility is that the tendency of raising only their own technical level, improving only their own management strengthens their consciousness of being keepers of small productive means or members of middle class, which will eventuate politically in the confirmation of old conservative attitude. 